\title{
Monitoring human genotoxicity risk associated to urban and industrial Buenos Aires air pollution exposure
}

\author{
María de los A. Gutiérrez ${ }^{1}$ - Mónica A. Palmieri ${ }^{2}$ - Daniela S. Giuliani ${ }^{1}$ • Jorge E. Colman Lerner ${ }^{3}$ (D) \\ Guillermo Maglione $^{4}$ • Darío Andrinolo ${ }^{1}$ - Deborah R. Tasat ${ }^{4,5}$
}

Received: 20 May 2019 / Accepted: 23 January 2020 / Published online: 8 February 2020

(C) Springer-Verlag GmbH Germany, part of Springer Nature 2020

\begin{abstract}
The quality of life in large megacities is directly affected by its air quality. In urban environments, suspended particles from anthropogenic origin is one of the main air contaminants identified as highly genotoxic, mutagenic, or carcinogenic. Atmospheric monitoring is therefore imperative, and bioassays to detect the effects of genotoxic agents give usually excellent results. Analysis of micronucleus (MN) in exfoliated oral mucosa cells is a sensitive non-invasive method for monitoring genetic damage in human populations. The first aim of this study was to analyze and characterize levels of volatile organic compounds (VOCs), particulate matter (PM), and polycyclic aromatic hydrocarbons (PAHs) in two areas from Buenos Aires: La Plata city, an urban (U) area and Ensenada, an industrial (I) area. Secondly, we evaluated the possible health risk of its inhabitants through a simple genotoxic assay on exfoliated oral mucosa cells. Whole blood cell count and nuclear abnormalities frequencies were evaluated in the exfoliated oral mucosa cells from urban and industrial inhabitants. Smoking habit represented a significant factor increasing MN percentage while, age did not increase the production of any of the nuclear aberrations assayed (micronuclei, binucleated, karyorrhexis) when the inhabitants from the urban and the industrial areas were compared. In addition, changes in $\mathrm{MN}$ and binucleated cell percentages in males and females were found to be area-dependent. We suggest that regardless PM concentration, PM-specific characteristics (size, shape, chemical elements, etc.) and VOCs levels could be responsible for the different harmful genotoxic effects seen in the two areas. Although this is a preliminary study, our results allowed to recognize that individuals living in both the urban and the industrial areas could be considered susceptible groups and should periodically undergo biological monitoring and appropriate care.
\end{abstract}

Keywords Air pollution $\cdot$ Urban environment $\cdot$ Industrial environment $\cdot$ Genotoxicity $\cdot$ Micronucleus

\section{Introduction}

Air pollution consisting of gases and particulate matter (PM) represents a health problem in urban centers worldwide resulting in 6.5 million premature deaths annually with $90 \%$ mortality in low or median-income countries (WHO 2018).

Responsible editor: Constantini Samara

Jorge E. Colman Lerner

jecolman@quimica.unlp.edu.ar

1 Center for Environmental Research (CIM) Faculty of Exact Sciences, CONICET, National University of La Plata, Boulevard 120 No. 1489, Buenos Aires, Argentina

2 Biodiversity and Experimental Biology Department, School of Exact and Natural Sciences, University of Buenos Aires, Av. Int. Güiraldes No. 2160, Buenos Aires, Argentina
The $54 \%$ of the world population live in urban areas where industrial and urban exhausts are the two main sources of air pollution. However, environmental air pollution depends not only on the source of emission and the quantities emitted but also, on local factors such as topography and weather conditions, therefore each city is a unique system.
3 Center for Research and Development in Applied Sciences (CINDECA), Faculty of Exact Sciences, CONICET, CIC-PBA, National University of La Plata, 47 y 115 No. 257, Buenos Aires, Argentina

4 Department of Histology and Embryology, School of Dentistry, University of Buenos Aires, Marcelo T. de Alvear 2142, Buenos Aires, Argentina

5 School of Science and Technology, National University of San Martín, 25 de Mayo y Francia, San Martín, Buenos Aires, Argentina 
In general, in urban areas, the number of vehicles is increasing three times faster than the rate of population growth, being diesel-burning buses and trucks the major source of airborne contamination. La Plata is the capital city of Buenos Aires Province, Argentina that according to the National census (INDEC 2011) has a population of 799,523 inhabitants. Public transportation network in La Plata city is very dense; vehicular traffic is intense comprising around 350,000 cars, 3100 taxis and rent-cars, and 640 buses (Frediani and López 2014). The vehicle fleet in this city is one of the principal sources of air pollution which contribution has increased significantly in the last 20 years (Colman Lerner et al. 2014b). Because of its demographic and transportation profile and because this city is placed in an area from Buenos Aires where the atmosphere has low self-cleansing capacity, vehicle combustion exhaust should be considered as an important cause of deterioration of La Plata atmosphere.

In the developing world, it is not uncommon to find in certain locations, a concentration of heavy industries, designated by governments as "development poles." One of the most important refineries in South America and one of the most dynamic industrial pole in Argentina is placed in the city of Ensenada. The refinery has a refining capacity of 200,000 barrels of crude oil per day obtaining a wide range of products with a yearly production of more than 650,000 tons. This refinery includes a production facility of base lubricants, paraffin, aromatics, asphalt, and petrochemical products. In this area, the rapid introduction of new and complex processes into a social context, not well prepared to control their potential associated risks (dumping of toxic wastes and by-products of technological processes), can result in serious consequences to the environment and the health of its inhabitants. Moreover, fine particles suspended in the air and PAHs associates, resulted from the incomplete burning of biomass and fossil fuels, leave a deposit of soot on surfaces, and have proven to be a major lung irritant (E. Ratto et al. 2018). Furthermore, Ensenada with 56,129 inhabitants (INDEC 2011) is not only an industrial, but a port which in 2014 was expanded and modernized having an operational capacity of 400 thousand containers per year.

Populations from urban and industrial areas are constantly exposed to an array of airborne toxic agents that might cause genetic damage, congenital defects, carcinogenesis, and shortened life expectancy (Hirvonen 1995; Brook et al. 2002; Kok et al. 2009; Sosa et al. 2017; Colman Lerner et al. 2018). In particular, La Plata conglomerate (La Plata city and its surrounding) has been considered one of the six most potentially air-polluted areas of Argentina (Petcheneshsky 1996) being air pollution one of the most important anthropic risks. In this sense, identifying and evaluating these hazardous xenobiotics might help take actions to decrease their presence in the environment and to minimize their potential adverse consequences on people's health.

In this regard, the first step to study the effects on exposed populations, is to conduct monitoring studies using pertinent equipment to analyze the air pollution. Secondly, it is important to screen the population by means of simple methods in order to detect and identify possible early-stage DNA damage.

Micronucleus (MN) assay in oral mucosal cells is not only a good indicator of chromosome mutations but a non-invasive, simple, rapid, and cheap test applicable to many cell types (Majer et al. 2001), frequently used in earlier occupational studies (Wultsch et al. 2014; LeónMejía et al. 2014; Idolo et al. 2018; Villarini et al. 2018). This assay allows not only to detect $\mathrm{MN}$ but also disturbances of the mitotic cycle leading to the formation of binucleated cells and other anomalies reflecting cytotoxic effects (karyorrhexis).

Micronuclei originate from structural and numerical chromosomal aberrations (Norppa and Falck 2003) and consist of acentric chromosomes, chromatid fragments, or whole chromosomes that have failed to be incorporated into the daughter nuclei during mitosis. The $\mathrm{MN}$ index in rodent and/or human cells has become one of the standard cytogenetic endpoints and biomarkers used in genetic toxicology in vivo or ex vivo. MN assay has been employed for exposed urban populations worldwide as an "endogenous dosimeter" in tissues that are specific targets of genotoxic and carcinogenic agents including particulate matter (Roubicek et al. 2007; Sellappa et al. 2010; Mørck et al. 2016). In humans, MN can be easily assessed in erythrocytes, lymphocytes, and exfoliated epithelial cells to obtain a measure of genome damage induced in vivo (Feretti et al. 2014; Bonetta et al. 2019). Further, the increased frequencies of $\mathrm{MN}$ in the lymphocytes have been associated with cancer risks (Bonassi et al. 2011).

The oral mucosa cells constitute a relevant tool in the biomonitoring of populations exposed to genotoxic and mutagenic agents (Holland et al. 2008). It has to be pointed out that $\mathrm{MN}$ in exfoliated cells is induced when the cells are in the basal layer, thus reflecting the genotoxic effect occurred during the last 3 weeks. In addition to $\mathrm{MN}$, meta-nuclear alterations such as binucleated cells, karyorrehxis, pyknosis, and chromosome bridges must be taken into account, as they are also indicative of genotoxicity (Tolbert et al. 1992).

The aim of this study was first to analyze and characterize air particulate matter of two different areas from Buenos Aires: La Plata city, an important vehicular transit area and Ensenada city, an industrial pole; and secondly to evaluate the possible health risk of its inhabitants through a simple genotoxic assay on exfoliated oral mucosa cells. 


\section{Materials and methods}

\section{Urban and industrial areas}

The coastal region of the edge of the Río de la Plata located in the north-eastern area of the province of Buenos Aires is an important socioeconomic development. La Plata, Berisso, and Ensenada cities particularly represent an area with strong anthropogenic activity (Kruse et al. 2011; Colman Lerner et al. 2014b). The coastal region is humid, owing to its coastal location; its average monthly humidity is higher than $65 \%$ and the average annual temperature is around $18-16^{\circ} \mathrm{C}$. As for the wind, its average annual intensity reaches $12-18 \mathrm{~km} / \mathrm{h}$, with prevailing winds coming from the East, Northeast, and Southwest (Fig. 1a).

La Plata $\left(34^{\circ} 55^{\prime} 17.2^{\prime \prime} \mathrm{S}, 57^{\circ} 57^{\prime} 16.3^{\prime \prime} \mathrm{W}\right)$ with a population of 799,523 inhabitants (INDEC 2011) and a dense public transportation network is the capital city of Buenos Aires Province, Argentina. Placed in a Buenos Aires area where the atmosphere has low self-cleansing capacity, vehicle combustion exhaust should be considered the main cause of its atmosphere deterioration.

The party of Ensenada is located to the East of the Province of Buenos Aires, on the South coast of the River of La Plata. It is $7 \mathrm{~km}$ from the city of La Plata and $65 \mathrm{~km}$ from the Autonomous City of Buenos Aires (Fig. 1). The City of Ensenada (34 $86^{\prime} 48^{\prime \prime} \mathrm{S}, 57^{\circ} 90^{\prime} 5^{\prime \prime}$ W) located by the small Ensenada Bay on the Río de la Plata has a population of 56,729 inhabitants (INDEC 2011). The port activity and the Free Zone and the Petrochemical Complex, rated as one of the most important South America, highlight its industrial, productive, and developmental nature of this city.

In this context, and due to the characteristics of the cities mentioned above, we considered La Plata as an urban area (U) and Ensenada as an industrial area (I).

\section{Particulate matter collection and morphochemical characteristics}

\section{Particulate matter collection}

Particulate matter levels both for $\mathrm{PM}_{10}$ and $\mathrm{PM}_{2.5}$ were monitored using MiniVol TAS (AirMetrics Co., Springfield, Oregon, USA) that draw air at $5 \mathrm{~L} / \mathrm{min}$ sequentially through a particle-size separator (impactor) and filter thereby capturing PM; polytetrafluoroethylene (PTFE) membrane of 46.2-mm diameter and 2- $\mu \mathrm{m}$ poresize was used as the filter. Both particles of size $<2.5 \mu \mathrm{m}$ $\left(\mathrm{PM}_{2.5}\right)$ and aerodynamic diameter $\leq 10 \mu \mathrm{m}\left(\mathrm{PM}_{10}\right)$ were detected. Gravimetry was used to determine the particle content in each sample. PM collection was carried out simultaneously in both areas following the methodology of (Gutierrez et al. 2019).

\section{PM morphological and chemical composition study}

Scanning electron microscopy (SEM) and energy dispersive X-ray spectroscopy (EDS) were employed to analyze particle morphology, size, and chemical composition from the industrial and the urban areas. Samples were analyzed

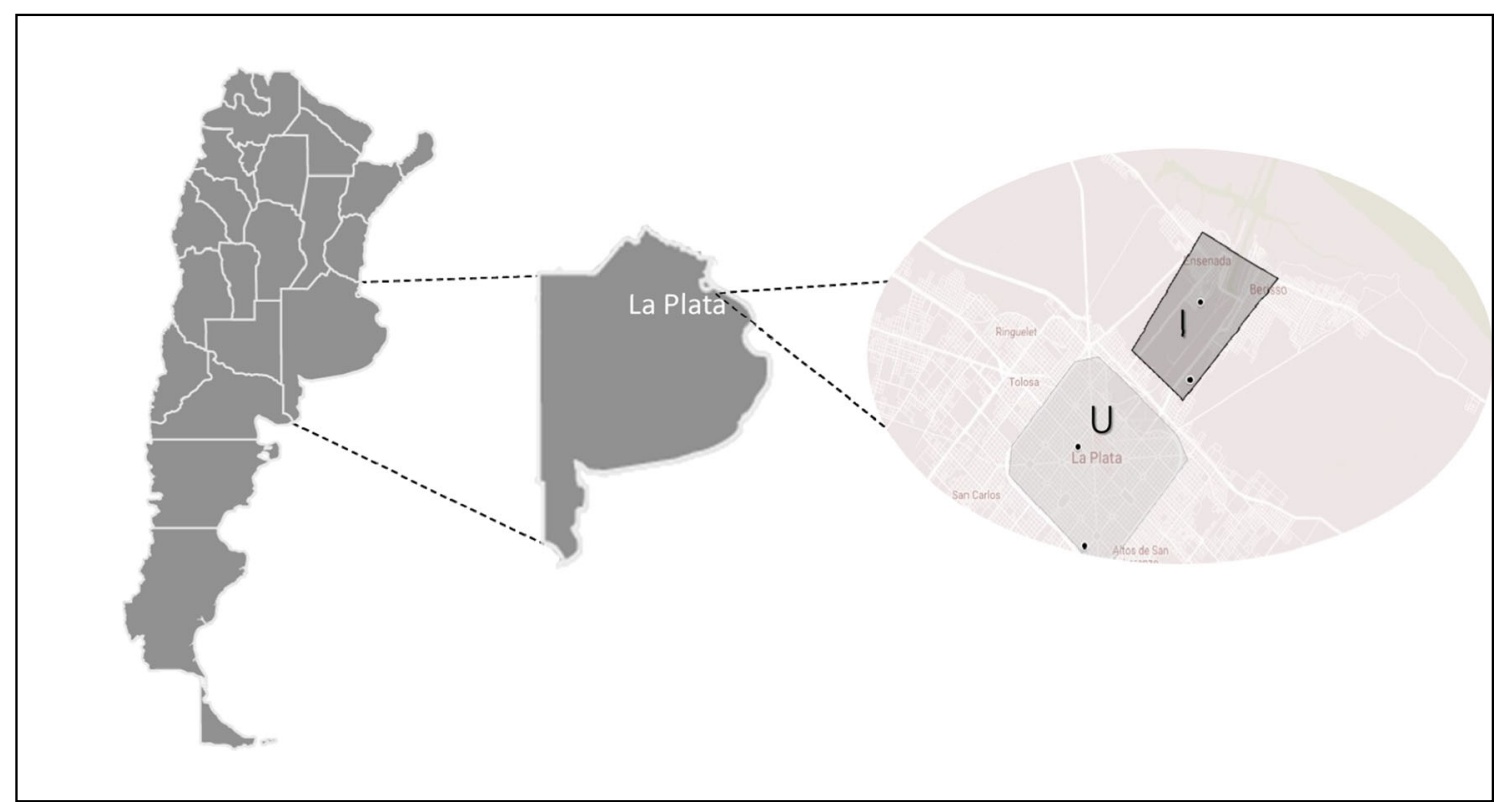

Fig. 1 Map of Argentine and Buenos Aires Province. Study areas are circumscribed: industrial zone (dark gray box) and urban zone (light gray box). Monitoring points in each area are shown as black dots 
using a Philips SEM 505 with EDS PRIME 10 Microprobe System.

\section{Polycyclic aromatic hydrocarbons (PAHs)}

The presence of PAHs was analyzed using high-performance liquid chromatography (HPLC) with fluorescence detection. 16 US EPA priority PAHs were detected: naphthalene (Naph), acenaphthylene (Acpy), acenapthene (Acp), fluorene (Flu), phenantrene(Pha), anthracene(Ant), fluoranthene(Fl), pyrene(Pyr), benzo(a)antrhacene(BaA), chrysene (Chr), benzo(b)fluoranthene $(\mathrm{BbF})$, benzo(k)fluoranthene $(\mathrm{BkF})$, benzo(a)pyrene (BaP), indeno(1,2,3-cd)pyrene(Ind), d i be nzo ( a, h ) a n thracene (D B A ), a n d benzo(g,h,i)perylene(BghiP). The methodology was performance like (Sosa et al. 2017).

\section{Volatile organic compounds (VOCs)}

The methodology used consisted in performing an active monitoring of VOCs (coal tube, skc17-01A) in the two study areas, at a flow rate of $0.21 \mathrm{~min}-1$ during $8 \mathrm{~h}$. The samples were analyzed by gas chromatography with mass spectrometry detector. The detection limits for all components were estimated as three times the standard deviation (SD) of five repeated measurements of unused (blank) tubes. Values of 0.01 to $0.05 \mathrm{ng} \mathrm{m}^{-3}$ were obtained for $8 \mathrm{~h}$ of sampling.

We analyzed 24 VOCs: hexane, ethyl acetate, chloroform, cyclohexane, carbon tetrachloride, benzene, 1,2-dichloroethane, heptane, 3-methyl-2-butanone, n-propyl acetate, methyl isobutyl ketone, toluene, perchlorethylene, acetate of butilo, chlorobenzene, ethylbenzene, $\mathrm{m}+\mathrm{p}$-xilene, nonane, o-xilene, ethoxyethyl acetate, cumene, cyclohexanone, undecane, and dodecane.

\section{Study population}

The study involved 57 volunteers $(n)$ whose ages range between 22 and 67 years old, living and working in: La Plata $(n=31)$ and Ensenada $(n=26)$, two different locations from Buenos Aires.

To eliminate different confounding factors that can influence chromosome mutation percentage, individuals from the industrial and the urban areas were chosen in a way so that they were comparable in age distribution, ethnicity, food lifestyle, nutritional status, as well as for the extent of indoor air pollution at their homes. Exclusion criteria included pregnancy or breastfeeding (in female volunteers), drug addictions, and smoking. The main characteristics showing the profile of the subjects who took part in this study are presented in Table 1.

All individuals signed a post-informed consent before inclusion in the study. Note: at the time of the study, none of the participants was under medical treatment involving drugs of any kind. The study was conducted according to the tenets of the Declaration of Helsinki(World Medical Association. 2001). The research protocol was approved by the Central Advisory Committee on Bioethics (Comité Consultivo Central de Bioética) of UNLP, and informed consent was obtained in all subjects before they were registered in the study.

\section{Blood samples and analysis}

Venous blood samples $(10 \mathrm{~mL})$ were collected from each individual by standard procedures and whole blood cell (WBC) count, and evaluation of its subpopulations was performed using an automatic biochemistry analyzer (Metrolab CM 250, Weiner lab). To prevent blood from clotting, $1.5 \mathrm{mg} /$ $\mathrm{mL}$ ethylene diamine tetra acetic acid (EDTA) was added in each tube. Patients from both the industrial and the urban area fasted $12 \mathrm{~h}$ previous to the blood extraction.

\section{Sample collection and nuclear aberrations assay}

Exfoliated epithelial cells from oral mucosa were collected by gently scraping the oral mucosa from the middle part of the inner cheeks with a wooden spatula. The cells were washed three times in $0.9 \%$ phosphate saline, then cells were smeared on slides, dried in air, and fixed with cold solution of $1 \%$ paraformaldehyde in $0.1 \mathrm{M}$ phosphate buffer $(\mathrm{pH}$ 7.2-7.4) for $20 \mathrm{~min}$. Slides were stained with Giemsa following Fenech et al. (2003) as was the criteria for the scoring of $\mathrm{MN}$. Briefly, MN were scored when MN diameter was $1 / 3$ of the main nucleus diameter or less, when they were round shaped, not refractile, not connected to the main nucleus, when they touched but not over-lapped the main nucleus, and when their chromatin structure and staining color were similar to those of the main nucleus.

Besides MN, other nuclear anomalies pyknosis (shrunken nuclei), karyorrhexis (nuclear disintegration), karyolysis (dissolution of nucleus), and binucleated cells were evaluated following the criteria of Tolbert et al. (1992). No less than 2000 cells from each person were analyzed and scored under light microscope with $\times 40$ and $\times 100$. Results are expressed as percentage of cell nuclear aberration.

\section{Statistical analysis}

The data acquired were tested for normality and heterogeneity of variance using Chi-Square analysis and Bartlett's test, respectively. Analysis of nuclear abnormalities was performed using a non-parametric Mann-Whitney test. Data are presented as the mean $\pm \mathrm{SD}$. $p$ value of $<0.05$ was considered to indicate statistical significance. All calculations were 
Table 1: Demographic population characteristics from Ensenada and La Plata zones.

\begin{tabular}{llllll}
\hline Parameters & \multicolumn{2}{l}{ Industrial zone Ensenada } & & \multicolumn{2}{l}{ Urban zone La Plata } \\
\cline { 2 - 3 } & Males $(n=16)$ & Females $(n=10)$ & & Males $(n=11)$ & Females $(n=20)$ \\
\hline Range eye (years) & $28-59$ & $37-60$ & & $24-56$ & $22-67$ \\
Current smoker $(\%)$ & 56.3 & 30 & & 9.1 & 10 \\
Food habit $(\%)$ & $\mathrm{b}=87.5 ; \mathrm{f}=12.5$ & $\mathrm{~b}=90 ; \mathrm{f}=10$ & & $\mathrm{~b}=100$ & $\mathrm{~b}=85 ; \mathrm{f}=10 \mathrm{v}=5$ \\
Weight $(\mathrm{kg})$ & $85.16 \pm 14.02$ & $74.56 \pm 13.75$ & & $80.64 \pm 13.43$ & $60.70 \pm 11.84$ \\
Height $(\mathrm{m})$ & $1.73 \pm 0.05$ & $1.62 \pm 0.06$ & & $1.76 \pm 0.09$ & $1.64 \pm 0.06$ \\
BMI $(\mathrm{kg} / \mathrm{m} 2)$ & $28.49 \pm 3.86$ & $28.58 \pm 5.20$ & & $25.94 \pm 3.93$ & $22.54 \pm 3.15$ \\
\hline
\end{tabular}

$\mathrm{F}=$ female, $\mathrm{M}=$ male, $\mathrm{b}=$ balanced, $\mathrm{v}=$ vegetarian, $\mathrm{f}=$ rich in fats performed with Infostat software (Universidad Nacional de Córdoba, Córdoba, Argentina) and Graphpad Prism.

\section{Results}

\section{Particulate matter collection and morphochemical characterization}

$\mathrm{PM}_{10}$ and $\mathrm{PM}_{2.5}$ concentration from industrial and urban areas are shown in Table $2 . \mathrm{PM}_{10}$ level was significantly higher in the industrial zone when compared with the urban area $(p<0.05)$ while $\mathrm{PM}_{2.5}$ level showed not statistically significant differences between areas.

The analysis of the micrographs is shown in each area (Fig. 2); the greatest variety of morphologies are found in the samples of the industrial area, standing out besides irregular particles, particle conglomerates, and particles of spherical shape $\left(\mathrm{PM}_{10}\right)$. Spherical particle morphology (mostly free or in conglomerates) is associated mainly to high temperatures incomplete combustion as occurs in the petrochemical pole located in the industrial region (Breed et al. 2002; Li and Shao 2009; González et al. 2017). Irregular geometry prevails in particle conglomerates. On the other hand, in the urban area, the lack of spherical particles is evident, with irregular geometry particles prevailing over the particle conglomerates.

The elemental analysis by EDS for both $\mathrm{PM}_{10}$ and $\mathrm{PM}_{2.5}$ shows a marked difference in the carbon $(\mathrm{C})$ level $(\sim 2$ fold $)$ when the two areas under study were compared. As was previously reported by González et al. (2018) and Dappe et al. (2018), the Ensenada area showed high content of C and low content of metal traces indicative of industrial activity being the main emission sources of the petrochemical industry and the production of petroleum coal (Fig. 3).

\section{PAHs}

PAHs concentration from industrial and urban areas are shown in Table 2. Although PAHs levels were not significantly different in both areas, $\mathrm{BaA}$ which have been identified as a compound associated to cancer risk included in group 1 by IARC was detected.

\section{VOCs}

Table 2 shows VOCs concentration detected in both areas studied. Form the 24 VOCs analyzed, 13 species presented values higher in the industrial with respect to the urban area being this differences statistically significant $(p<0.05)$. Among them, according to IARC, 1,2 dichloroethane and benzene are considered possibly carcinogenic where benzene was identified as carcinogenic to humans. In our populations, although the average industrial values were higher, if we take into account the LCR index (Life time cancer risk), following the methodology of Colman et al. (2013 and 2018), both populations have values of $4.2 \times$ $10^{-7}$ (I) and $1.5 \times 10^{-7}(\mathrm{U})$. The WHO considers as acceptable a LCR between $1 \times 10^{-5}$ and $1 \times 10^{-6}$, whereas values lower than $10 \times 10^{-6}$ were recommended by USEPA.

\section{Sample collection and nuclear aberrations assay}

In order to validate our experimental protocol, we first analyzed micronuclei $(\mathrm{MN})$ presence in the smoker and nonsmoker populations from the industrial area (Fig. 4). MN percentage showed a significant difference between both populations assayed (non-smoker $=0.74 \pm 0.52$ vs. smoker $=2.35 \pm$ 1.08 mean $\pm \mathrm{SD}, p<0.05$ ). This result shows that smoking is a factor that significantly modifies MN percentage.

Therefore, as smoking was found to be a cofounding factor which can mask air pollution effects on oral mucosa cells, we followed our study only by analyzing the non-smoker population from both the industrial and the urban areas. The comparative analysis, only for the non-smoker population, showed no differences in the MN percentage between areas (Fig. 5). Nevertheless, as nuclear aberrations could vary with sex, we sought to determine the MN, binucleated cell, and karyorrhexis percentage for non-smokers females vs. males within the two areas (Fig. 6).

Furthermore, we also analyzed MN, binuclated cells, and kariorrhexis frequency with regard to age. We 
Table 2: PM, VOCs and PAHs concentrations from Ensenada and La Plata zones.

\begin{tabular}{|c|c|c|c|c|c|}
\hline & & \multicolumn{2}{|c|}{ Industrial zone Ensenada } & \multicolumn{2}{|c|}{ Urban zone La Plata } \\
\hline & & $n$ & mean $\pm \mathrm{SD}$ & $n$ & mean $\pm \mathrm{SD}$ \\
\hline \multirow[t]{2}{*}{ PM } & $\mathrm{PM}_{10}\left[\mu \mathrm{g} / \mathrm{m}^{3}\right]$ & 14 & $52.2 \pm 16.7^{*}$ & 14 & $31.9 \pm 13.9^{*}$ \\
\hline & $\mathrm{PM}_{2.5}\left[\mu \mathrm{g} / \mathrm{m}^{3}\right]$ & 26 & $16.8 \pm 9.5$ & 15 & $16.7 \pm 12.2$ \\
\hline \multirow[t]{24}{*}{ VOCs } & Hexane & 22 & $7.7 \pm 7.4^{*}$ & 25 & $2.5 \pm 5.0 *$ \\
\hline & Ethyl acetate & 22 & $3.3 \pm 4.3$ & 25 & $2.1 \pm 3.1$ \\
\hline & Chloroform & 22 & $0.1 \pm 0.4$ & 25 & $0.1 \pm 0.4$ \\
\hline & Cyclohexane & 22 & $2.97 \pm 3.33$ & 25 & $1.96 \pm 3.95$ \\
\hline & Carbon tetrachloride & 22 & $0.2 \pm 0.68$ & 25 & $0.09 \pm 0.33$ \\
\hline & Benzene & 22 & $0.56 \pm 0.72 *$ & 25 & $0.2 \pm 0.19^{*}$ \\
\hline & 1,2-dichloroethane & 22 & $0.16 \pm 0.64 *$ & 25 & $0.00029 \pm 0.0015^{*}$ \\
\hline & Heptane & 22 & $0.46 \pm 0.74$ & 25 & $0.2 \pm 0.2$ \\
\hline & 3-methyl-2-butanone & 22 & $0.06 \pm 0.27$ & 25 & $0.03 \pm 0.15$ \\
\hline & n-propyl acetate & 22 & $0.0027 \pm 0.01$ & 25 & $0.00032 \pm 0.0016$ \\
\hline & Methyl isobutyl ketone & 22 & $0.15 \pm 0.17 *$ & 25 & $0.05 \pm 0.06^{*}$ \\
\hline & Toluene & 22 & $3.3 \pm 3.4$ & 25 & $1.72 \pm 1.86$ \\
\hline & Perchlorethylene & 22 & $0.81 \pm 1.49$ & 25 & $0.46 \pm 0.66$ \\
\hline & acetate of butilo & 22 & $2.01 \pm 6.45^{*}$ & 25 & $0.41 \pm 0.34^{*}$ \\
\hline & Chlorobenzene & 22 & $0.02 \pm 0.01 *$ & 25 & $0.01 \pm 0.01 *$ \\
\hline & Ethylbenzene & 22 & $0.38 \pm 0.67 *$ & 25 & $0.13 \pm 0.09 *$ \\
\hline & $m+p$-Xilene & 22 & $2.73 \pm 4.01 *$ & 25 & $0.95 \pm 0.76^{*}$ \\
\hline & Nonane & 22 & $2.59 \pm 4.96^{*}$ & 25 & $0.64 \pm 0.58^{*}$ \\
\hline & o-Xilene & 22 & $3.93 \pm 6.09 *$ & 25 & $1.05 \pm 1.13^{*}$ \\
\hline & Ethoxyethylacetate & 22 & $2.55 \pm 7.95$ & 25 & ND \\
\hline & Cumene & 22 & $0.33 \pm 0.63$ & 25 & $0.14 \pm 0.15$ \\
\hline & Cyclohexanone & 22 & $8.37 \pm 17.97^{*}$ & 25 & $2.26 \pm 1.43^{*}$ \\
\hline & Undecane & 22 & $7.63 \pm 7.76^{*}$ & 25 & $3.36 \pm 3.35^{*}$ \\
\hline & Dodecane & 22 & $7.33 \pm 6.5^{*}$ & 25 & $3.29 \pm 2.72 *$ \\
\hline \multirow[t]{16}{*}{ HAPs } & Naph & 15 & ND & 8 & ND \\
\hline & Acpy & 15 & ND & 8 & ND \\
\hline & Acp & 15 & ND & 8 & ND \\
\hline & Flu & 15 & $4.14 \pm 8.36$ & 8 & $6.38 \pm 11.87$ \\
\hline & Pha & 15 & $1.17 \pm 2.81$ & 8 & $1.11 \pm 2.5$ \\
\hline & Ant & 15 & $7.63 \pm 12.46$ & 8 & $7.15 \pm 10.2$ \\
\hline & $\mathrm{Fl}$ & 15 & $0.02 \pm 0.04$ & 8 & ND \\
\hline & Pyr & 15 & ND & 8 & ND \\
\hline & $\mathrm{BaA}$ & 15 & $0.14 \pm 0.16$ & 8 & $0.1 \pm 0.28$ \\
\hline & $\mathrm{Chr}$ & 15 & ND & 8 & ND \\
\hline & $\mathrm{BbF}$ & 15 & $0.42 \pm 0.47$ & 8 & $0.08 \pm 0.08$ \\
\hline & $\mathrm{BkF}$ & 15 & $0.27 \pm 0.31$ & 8 & $0.19 \pm 0.37$ \\
\hline & $\mathrm{BaP}$ & 15 & $0.13 \pm 0.11$ & 8 & $0.1 \pm 0.27$ \\
\hline & DBA & 15 & $0.03 \pm 0.07$ & 8 & ND \\
\hline & BghiP & 15 & $0.58 \pm 0.45$ & 8 & $0.25 \pm 0.44$ \\
\hline & Ind & 15 & $3.33 \pm 10.07$ & 8 & $0.87 \pm 2.47$ \\
\hline
\end{tabular}

Results are expressed as the mean $\pm \mathrm{SD}$. Asterisks $(*)$ show statistical significance at $\mathrm{p}<0,05 \mathrm{ND}=$ Not detectable evaluated nuclear aberrations within three age intervals: young adult (18-35), middle-aged adult (36-55), and older adult $(>55)$ as described elsewhere (Petry 2002).
No differences were detected for any of the nuclear aberrations among the different age groups evaluated (data not shown). 
Fig. 2 Particulate matter morphology. Representative SEM images of samples collected in urban and industrial zones: a $\mathrm{U}$

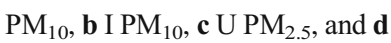
$\mathrm{IPM}_{2.5}$
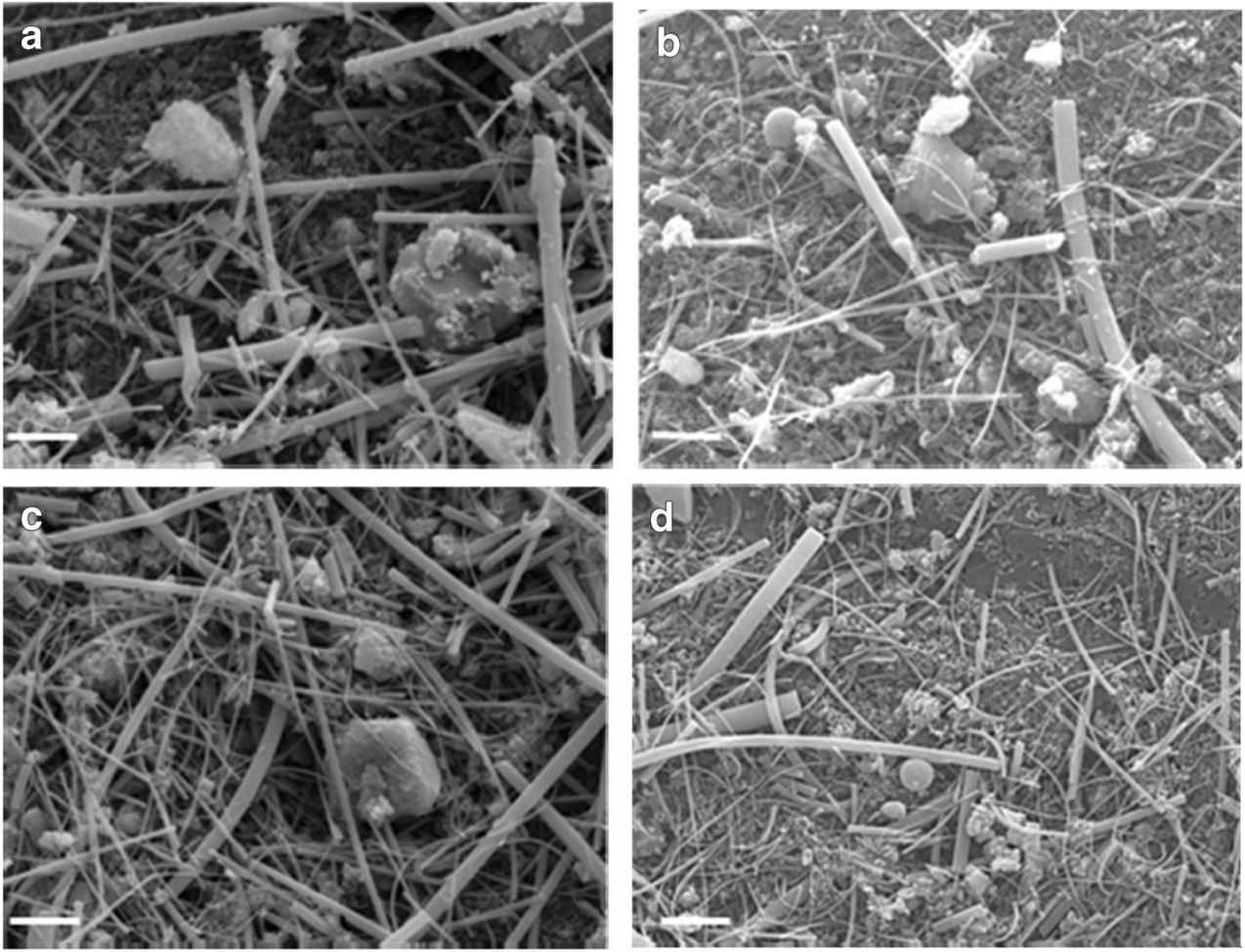

\section{Blood biochemical analysis}

Physiologic and pathologic processes may cause certain alterations in the total and absolute differential whole blood cell counts. Therefore, the identification of the leukogram pattern is key to the interpretation of changes in hemogram results.
Toxic changes are frequently seen as part of an inflammatory leukogram. As smoking was found to be a strong cofounder influencing MN percentage, the biochemical study was carried out only by analyzing the non-smoker individuals from both the industrial and the urban areas. We found no changes in the leukogram pattern neither in the population exposed to
Fig. 3 Particulate matter chemical composition from industrial and urban zones. Elemental analysis was performed by SEM-EDS
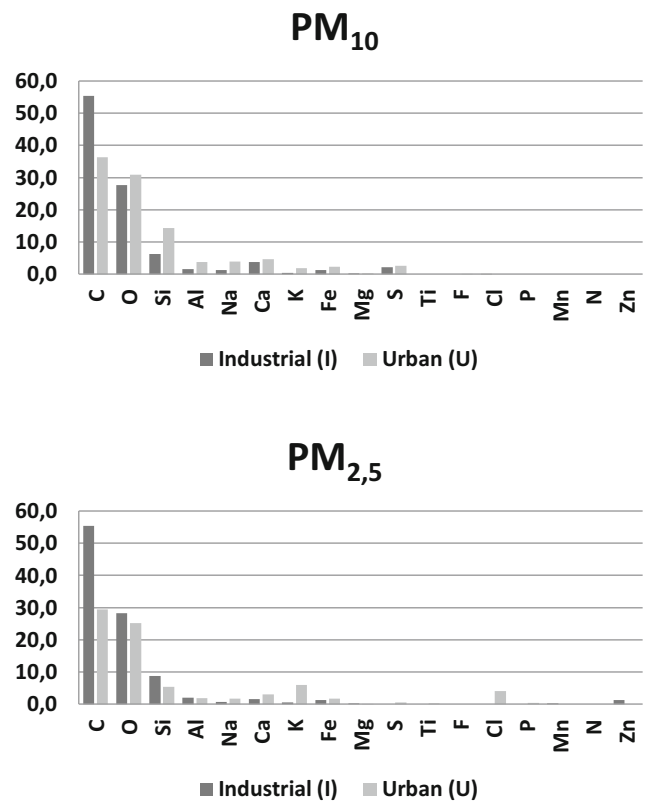


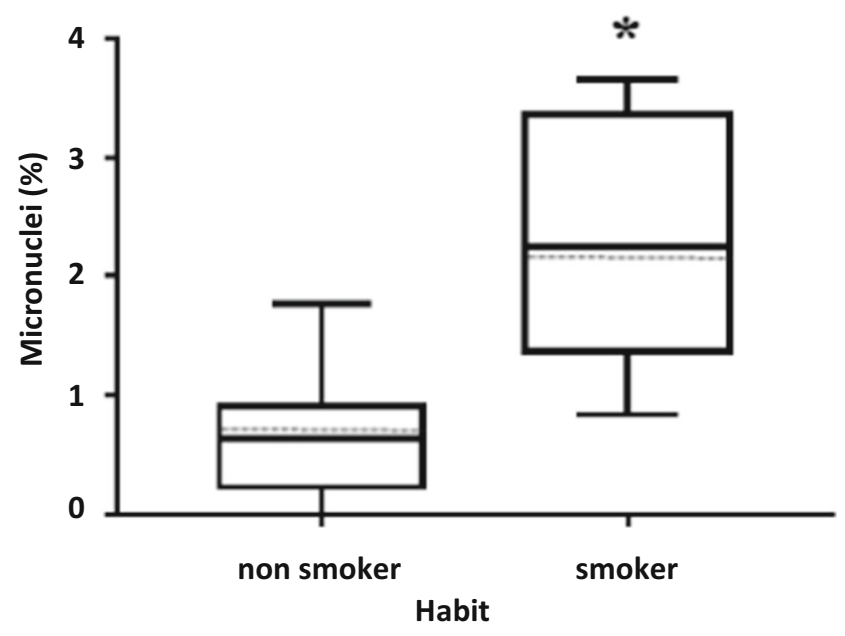

Fig. 4 Box and whisker plots of micronuclei from smokers and nonsmokers in the industrial zone. Median (solid line), mean (dotted line). Asterisks (*) show statistical significance at $p<0.05$

industrial air pollution nor in the population exposed to urban air pollution (Table 3 ).

\section{Statistical analyses}

The data acquired were tested for normality and heterogeneity of variance using Chi-Square analysis and Bartlett's test, respectively. Student's $t$ test was performed for normally distributed data, to determine statistically significant differences between two means. $p$ value of $<0.05$ was considered to indicate statistical significance. All calculations were performed with Infostat software (Universidad Nacional de Córdoba,

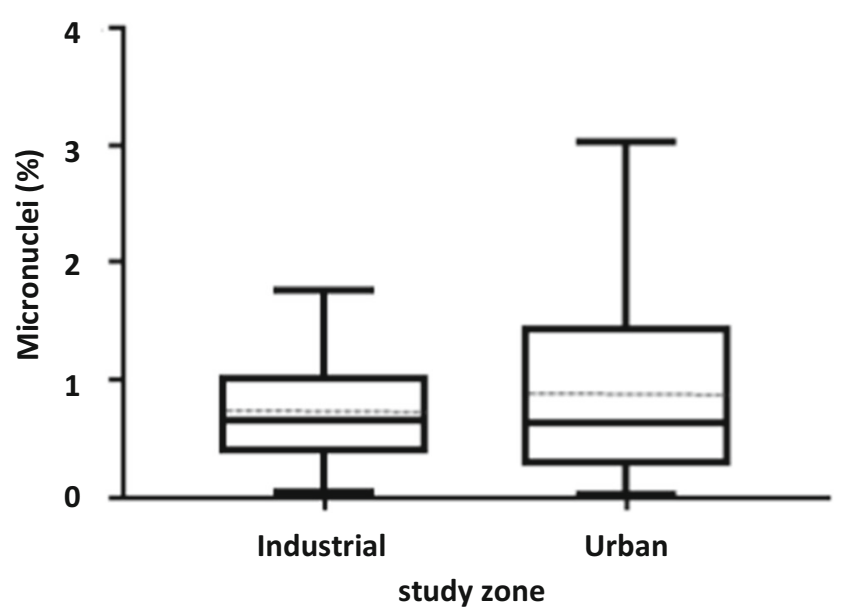

Fig. 5 Box and whisker plots of micronuclei from non-smokers in the industrial and urban zone. Industrial zone: Ensenada; Urban zone: La Plata median (solid line), mean (dotted line). No significant differences were found between zones
Córdoba, Argentina) and the box graphics with the Graphpad Prism software.

\section{Discussion}

Megacities atmospheres contain complex mixtures of air pollutants including mutagenic and carcinogenic substances such as diesel soot, heavy metals, and semi volatile organic compounds (VOCs) such as polycyclic aromatic hydrocarbons (PAHs). Oral mucosa cells are the first barrier for the inhalation route for air pollutants and are capable of metabolizing proximate carcinogens to reactive products (Vondracek et al. 2001; Spivack et al. 2004). Approximately $90 \%$ of human cancers originate from epithelial cells (Rosin 1992). Thus, it could be argued that oral epithelial cells represent a preferred target site for early genotoxic events induced by carcinogenic agents entering the body mainly via inhalation and ingestion. In this context, herein we studied the exfoliated oral mucosa cells profile and its possible association to environmental PM levels from two different areas of Buenos Aires megacity: the city of Ensenada, an industrial area (I) and the city of La Plata, an urban area (U).

The industrial area is mainly related to the national petrochemical industry and the generation of petroleum coke. Both industries are important sources of PM emission, with the petrochemical industry also being an important source of VOC's emissions. Previous studies showed that VOC's levels in this area are higher than in the urban area. More recently, as traffic became an important source of emission in both regions, VOC's levels have substantially increased (Massolo et al. 2009; Colman Lerner et al. 2014a, b).

Regarding PM concentration, annual averages for both sampling sites exceed guideline values of $20 \mu \mathrm{g} / \mathrm{m}^{3}$ (WHO 2006). It is noteworthy to point out that in the industrial area, PM levels (mainly PM10) almost doubled the amount of PM at the urban site (Wichmann et al. 2009; Colman Lerner 2013) exceeding not only the WHO guidance values but also the local legislation guideline values (Vidal 2018). Air particles from the industrial and urban areas analyzed by SEM-EDS showed distinct morphology as well as differences in carbon levels, which were always higher in the industrial zone. The latter might be probably associated with emissions from the petrochemical pole. Even though no differences in PAHs concentration were observed between the areas studied, the presence of BaA identified by IARC as carcinogenic was detected. Average VOCs levels were always higher in the industrial area including carcinogenic (benzene) or possibly carcinogenic (dichloroethane and benzene) species, although based on the LCR (Life time Cancer Risk), both populations in accordance with WHO and EPA, have acceptable values. These results could reflect the petrochemical pole activity (Colman Lerner et al. 2013, 2014a, b). As shown herein, PM morphological 

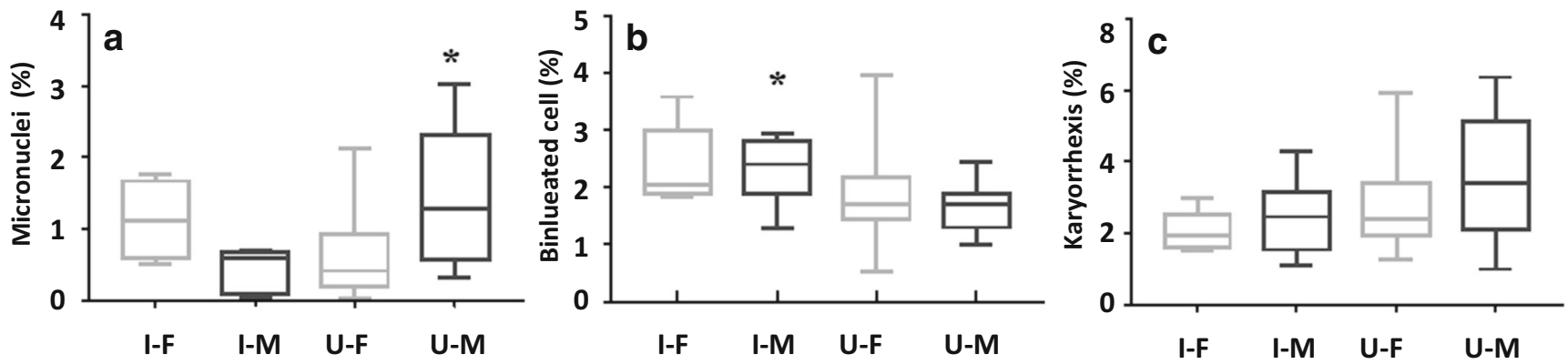

Fig. 6 Nuclear aberration by zone and gender. a Micronuclei. b Binucleated cell. c Karyorrhexis cell percentage. I, industrial zone (Ensenada); U, urban zone (La Plata); F, female; M, male. Box and whisker plots. Asterisks (*) show statistical significance at $p<0.05$. Median (solid line)

and chemical determination allows us identify air quality differences in the two studied areas.

To detect and identify possible early-stage DNA damage in the individuals exposed to different PM levels, we monitored employing a simple method, the frequency of nuclear aberrations in exfoliated oral mucosa cells from subjects living and working in two areas (U and I) from Buenos Aires.

The micronuclei (MN) frequency variation observed within the exposed groups, characterized by the high values of the standard deviation, must be due to the fact that the response to a given genotoxic agent is different from person to person. This differential response may be the result of different factors, such as genetic constitution and life habits. In this sense, sex and the habit of smoking are widely considered confounding factors (Maffei et al. 2002). Therefore, to establish whether these factors could exert any additional effect, we determined the frequency of micronuclei between smokers vs. non-smokers. The smoking habit is widely accepted as a major cause of bladder cancer, since $50 \%$ of the cases were identified in smoking men and $33 \%$ in smoking women (Silverman et al. 1992). When analyzing exfoliated oral mucosa cells Fontham et al. (1986), detected a sixfold increase in the number of MN in smokers; Reali et al. (1987) also reported an increase in the number of MN, and Burgaz et al. (1995) found a significant increase in micronucleated cells $(p<0.001)$ in smokers, as compared to non-smokers. In accordance with these and other researchers, we found a highly significant increase in the micronuclei frequency $(p<0.001)$ between smokers and non-smokers from the industrial area.

Although many studies report the age and gender of the subjects studied, only a fraction were able to establish a statistically significant effect by age (Gattás et al. 2001; Özkul et al. 1997) or by gender (Fenech et al. 1999; Pastor et al. 2001). When MN frequency in relation to the age of the individuals was evaluated, no differences are found between the two populations assayed (data not shown).

On the other hand, when MN frequency within each populations was evaluated with regard to sex, we observed significant differences between male-female MN. The same pattern was observed for binucleated cells. These results could be reflecting the greater chromosomal instability that men present with respect to women, making them more sensitive to genotoxic effects.

Because of the significant increase of modified chromosomes which happens together with the increase in age, irrespective of the gender, some studies show a positive association between age and MN frequency (Nath et al. 1995; Calvert et al. 1998; Fenech et al. 1999).

Frequency of micronucleated cells was $7.84 \pm 7.35$ per 1000 in the industrial population and was shown to have a large inter-individual variability. The study of factors contributing to this variability showed that smoking and sex could affect nuclear aberration rate.

The results allowed to conclude that the individuals living both in the industrial and urban areas, where the air quality are

Table 3. Industrial and urban population leukogram pattern.

\begin{tabular}{|c|c|c|c|c|c|}
\hline & \multicolumn{2}{|c|}{ Industrial zone Ensenada } & \multicolumn{2}{|c|}{ Urban zone La Plata } & \multirow{2}{*}{$\begin{array}{l}\text { Reference valor } \\
\text { range }\end{array}$} \\
\hline & mean $\pm \mathrm{SD}$ & range & mean $\pm \mathrm{SD}$ & range & \\
\hline Total Leukocytes & $7.2 \pm 2.2$ & $2.9-9.9$ & $6.6 \pm 2.1$ & $2.9-11.9$ & $5.0-10$ \\
\hline Lymphocytes & $2.4 \pm 0.6$ & $1.5-3.2$ & $2.4 \pm 0.7$ & $1.1-3.7$ & $1.3-4$ \\
\hline Monocytes & $0.6 \pm 0.1$ & $0.3-0.8$ & $0.5 \pm 0.2$ & $0.2-1.1$ & $0.2-0.8$ \\
\hline Neutrophils & $3.8 \pm 1.2$ & $1.1-5.1$ & $3.4 \pm 1$ & $1.6-5.6$ & $2-7.5$ \\
\hline Eosinophils & $0.3 \pm 0.2$ & $0.03-0.65$ & $0.3 \pm 0.3$ & $0.1-1.4$ & $0.05-0.5$ \\
\hline Basophils & $0.04 \pm 0.03$ & $0-0.11$ & $0.03 \pm 0.02$ & $0-0.09$ & $0-0.2$ \\
\hline
\end{tabular}

Results are expressed as unit $\times 10^{3} / \mathrm{mm}^{3}$, mean \pm SD. 
different, still could be considered to be at risk and should periodically undergo biological monitoring and appropriate care.

\section{Conclusions}

This study associates $\mathrm{PM}\left(\mathrm{PM}_{2.5}\right.$ and $\left.\mathrm{PM}_{10}\right), \mathrm{PAHs}$, and VOCs levels with oral mucosa genotoxicity. To this end, the frequency of nuclear aberrations in exfoliated oral mucosal cells from populations exposed to different levels of air quality was evaluated. It is noteworthy to mention that the population from the industrial area, exposed to a higher $\mathrm{PM}_{10}$ level $(p<0.05)$ and some VOCs like benzene, dichloroethane, and ethylbenzene showed no significant increases in MN percentage with respect to the urban population. This preliminary study, allowed us to recognize that individuals living in both areas could be considered as susceptible groups and should periodically undergo biological monitoring and appropriate care. Further studies with a larger sample of inhabitants should be done in order to confirm the data obtained herein.

Funding information The present study received financial support from the National University of La Plata (UNLP), University of Buenos Aires (UBA), National University of San Martín (UNSAM), the National Council of Scientific and Technical Research (CONICET), the Scientific Research Center (CIC), and the National Agency for Scientific and Technological Promotion, PICT Subsidy 2012-0328y.

\section{Compliance with ethical standards}

Conflict of interest The authors declare that they have no conflict of interest.

\section{References}

Bonassi S, El-Zein R, Bolognesi C, Fenech M (2011) Micronuclei frequency in peripheral blood lymphocytes and cancer risk: evidence from human studies. Mutagenesis 26:93-100. https://doi.org/10. 1093/mutage/geq075

Bonetta S, Bonetta S, Schilirò T, Ceretti E, Feretti D, Covolo L, Vannini S, Villarini M, Moretti M, Verani M, Carducci A, Bagordo F, de Donno A, Bonizzoni S, Bonetti A, Pignata C, Carraro E, Gelatti U, MAPEC_LIFE Study Group (2019) Mutagenic and genotoxic effects induced by PM0.5 of different Italian towns in human cells and bacteria: the MAPEC_LIFE study. Environ Pollut 245:1124-1135

Breed C, Arocena J, Sutherland D (2002) Possible sources of PM10 in Prince George (Canada) as revealed by morphology and in situ chemical composition of particulate. Atmos Environ 36:17211731. https://doi.org/10.1016/S1352-2310(01)00500-3

Brook RD, Brook JR, Urch B, Vincent R, Rajagopalan S, Silverman F (2002) Inhalation of fine particulate air pollution and ozone causes acute arterial vasoconstriction in healthy adults. Circulation 105: 1534-1536. https://doi.org/10.1161/01.CIR.0000013838.94747.64

Burgaz S, İșcan A, Büyükbingöl ZK et al (1995) Evaluation of micronuclei in exfoliated urothelial cells and urinary thioether excretion of smokers. Mutation Res/Environ Mutagenesis Related
Subjects 335:163-169. https://doi.org/10.1016/0165-1161(95) 90052-7

Calvert GM, Talaska G, Mueller CA et al (1998) Genotoxicity in workers exposed to methyl bromide. Mutation Res/Genet Toxicol Environ Mutagen 417:115-128. https://doi.org/10.1016/S1383-5718(98) 00105-3

Colman Lerner JE (2013) Contaminación ambiental análisis y mitigación/remoción de material particulado (MP) y compuestos orgánicos volátiles (COVs) y semivolátiles (COSVs). Doctoral thesis, National University of La Plata, Faculty of Exact Sciences, 231pp. http://sedici.unlp.edu.ar/bitstream/handle/10915/27002/ Documento_completo.pdf?sequence=1\&isAllowed=y

Colman Lerner JE, Morales A, Aguilar M, et al (2013) Air pollution and health effects on children. Comparative study between La Plata and Bahia Blanca, Buenos Aires, Argentina. In: Libro de memorias del IV Congreso Colombiano y Conferencia Internacional de Calidad del Aire y Salud Pública (CASAP IV)., JORGE E.PA. pp 223-232

Colman Lerner JE, Kohajda T, Aguilar ME et al (2014a) Improvement of health risk factors after reduction of VOC concentrations in industrial and urban areas. Environ Sci Pollut Res Int 21:9676-9688. https://doi.org/10.1007/s11356-014-2904-x

Colman Lerner JE, Morales A, Aguilar M, Giulani D, Orte M, Ditondo J, Porta A (2014b) The effect of air pollution on children's health: a comparative study between La Plata and Bahía Blanca, Buenos Aires Province, Argentina. WIT Transactions on Ecology and the Environment 181:659-670

Colman Lerner JE, Gutierrez M d 1 A, Mellado D et al (2018) Characterization and cancer risk assessment of VOCs in home and school environments in gran La Plata, Argentina. Environ Sci Pollut Res 25:10039-10048. https://doi.org/10.1007/s11356-018-1265-2

Dappe V, Uzu G, Schreck E et al (2018) Single-particle analysis of industrial emissions brings new insights for health risk assessment of PM. Atmos Pollut Res 9:697-704. https://doi.org/10.1016/J.APR. 2018.01.016

Fenech M, Holland N, Chang WP, Zeiger E, Bonassi S (1999) The HUman MicroNucleus project - an international collaborative study on the use of the micronucleus technique for measuring DNA damage in humans. Mutation Res/Fundament Molec Mech Mutagen 428:271-283. https://doi.org/10.1016/S1383-5742(99)00053-8

Fenech M, Chang WP, Kirsch-Volders M, Holland N, Bonassi S, Zeiger E (2003) HUMN project: detailed description of the scoring criteria for the cytokinesis-block micronucleus assay using isolated human lymphocyte cultures. Mutation Research/Genetic Toxicology and Environmental Mutagenesis 534(1-2):65-75

Feretti D, Ceretti E, De Donno A et al (2014) Monitoring air pollution effects on children for supporting public health policy: the protocol of the prospective cohort MAPEC study. BMJ Open 4:e006096

Fontham E, Correa P, Rodriguez E, Lin Y (1986) Validation of smoking history with the micronuclei test. In: agris.fao.org, D. Hoffman. Mechanisms in tobacco carcinogenesis, Banbury report, pp 113-119

Frediani JC, López MJ (2014) Revista Transporte y Territorio : revista del Programa Transporte y Territorio. UBA, Instituto de Geografía, Filo

Gattás GJ, Cardoso L d A, Medrado-Faria M d A, Saldanha PH (2001) Frequency of oral mucosa micronuclei in gas station operators after introducing methanol. Occupational Med (Oxford, England) 51: $107-113$

González LT, Rodríguez FL, Sánchez-Domínguez M, Cavazos A, LeyvaPorras C, Silva-Vidaurri L G, Barbosa JA (2017) Determination of trace metals in TSP and PM2. 5 materials collected in the Metropolitan Area of Monterrey, Mexico: A characterization study by XPS, ICP-AES and SEM-EDS. Atmospheric Research 196:8-22

González LT, Longoria-Rodríguez FE, Sánchez-Domínguez M et al (2018) Seasonal variation and chemical composition of particulate matter: a study by XPS, ICP-AES and sequential microanalysis using Raman with SEM/EDS. J Environ Sci 74:32-49. https://doi. org/10.1016/J.JES.2018.02.002 
Gutierrez MDLA, Colman Lerner JE, Giuliani DS, Porta AA, Andrinolo D (2019) Comparative study of tear lipid composition in two human populations with different exposure to particulate matter in La Plata, Argentina. Environ Sci Pollut Res 26:6948-6956. https://doi.org/10. 1007/s11356-019-04134-0

Hirvonen A (1995) Genetic factors in individual responses to environmental exposures. J Occup Environ Med 37:37-43

Holland N, Bolognesi C, Kirsch-Volders M, Bonassi S, Zeiger E, Knasmueller S, Fenech M (2008) The micronucleus assay in human buccal cells as a tool for biomonitoring DNA damage: the HUMN project perspective on current status and knowledge gaps. Mutation Res/Rev Mutation Res 659:93-108. https://doi.org/10.1016/J. MRREV.2008.03.007

Idolo A, Grassi T, Bagordo F et al (2018) Micronuclei in exfoliated buccal cells of children living in a cluster area of Salento (Southern Italy) with a high incidence of lung cancer: the IMP.AIR study. Int J Environ Res Public Health 15(8): 1659

Instituto Nacional de Esadística y Censos (INDEC) (2011) https:// www.indec.gob.ar/indec/web/Nivel4-CensoNacional-999-999Censo-2010 kok et al 2009. Programa de las Naciones Unidas para el Medio Ambiente. Oficina Regional para América latina y el caribe. http://www.pnuma.org/educamb/documentos/salud_ambiental_ basica.pdf.

Kok A, Yassi T, Kjellström T, Guidotti L (2009) Salud Ambiental Básica

Kruse E, Sarandón R, Schnack E, et al (2011) El cambio climático y las condiciones ambientales en los Partidos de La Plata, Berisso y Ensenada, Provincia de Buenos Aires: aspectos preliminares. III Congreso Internacional sobre Cambio Climático y Desarrollo Sustentable, 8 al 11 de agosto de 2011, La Plata, Argentina 9

León-Mejía G, Quintana M, Debastiani R, Dias J, Espitia-Pérez L, Hartmann A, Henriques JA, da Silva J (2014) Genetic damage in coal miners evaluated by buccal micronucleus cytome assay. Ecotoxicol Environ Saf 107:133-139. https://doi.org/10.1016/J. ECOENV.2014.05.023

Li W, Shao L (2009) Transmission electron microscopy study of aerosol particles from the brown hazes in northern China. J Geophys Res 114:9302. https://doi.org/10.1029/2008JD011285

Maffei F, Angelini S, Forti GC, Lodi V, Violante FS, Mattioli S, Hrelia P (2002) Micronuclei frequencies in hospital workers occupationally exposed to low levels of ionizing radiation: influence of smoking status and other factors. Mutagenesis 17:405-409. https://doi.org/ 10.1093/mutage/17.5.405

Majer BJ, Laky B, Knasmüller S, Kassie F (2001) Use of the micronucleus assay with exfoliated epithelial cells as a biomarker for monitoring individuals at elevated risk of genetic damage and in chemoprevention trials. Mutation Res/Rev Mutation Res 489:147-172. https://doi.org/10.1016/S1383-5742(01)00068-0

Massolo L, Rehwagen M, Porta A et al (2009) Indoor-outdoor distribution and risk assessment of volatile organic compounds in the atmosphere of industrial and urban areas. Environ Toxicol 25:339-349. https://doi.org/10.1002/tox.20504

Mørck TA, Vande Loock K, Bech Poulsen M et al (2016) Micronucleus frequency in Danish schoolchildren and their mothers from the DEMOCOPHES population. Mutagenesis 31:1-8. https://doi.org/ 10.1093/mutage/gev054

Nath J, Tucker JD, Hando JC (1995) Y chromosome aneuploidy, micronuclei, kinetochores and aging in men. Chromosoma 103: 725-731. https://doi.org/10.1007/BF00344234

Norppa H, Falck GC-M (2003) What do human micronuclei contain? Mutagenesis 18:221-233

Özkul Y, Donmez H, Erenmemisoglu A et al (1997) Induction of micronuclei by smokeless tobacco on buccal mucosa cells of habitual users. Mutagenesis 12:285-287. https://doi.org/10.1093/ mutage/12.4.285

Pastor S, Gutiérrez S, Creus A, Cebulska-Wasilewska A, Marcos R (2001) Micronuclei in peripheral blood lymphocytes and buccal epithelial cells of polish farmers exposed to pesticides. Mutation Res/Genet Toxicol Environ Mutagen 495:147-156. https://doi.org/ 10.1016/S1383-5718(01)00206-6

Petcheneshsky T (1996) Ministerio De Salud y Acción Social Subsecretaria de Atencion Comunitaria Departamento de Salud Ambiental. Situacion del monitoreo de la calidad del aire en la republica argentina. http://www.msal.gob.ar/ politicassocioambientales/images/stories/descargas/recursos/1997 tpetcheneshsky_calidad_del_aire_en_la_ra.pdf

Petry NM (2002) A comparison of young, middle-aged, and older adult treatment-seeking pathological gamblers. The Gerontologist 42:92 99. https://doi.org/10.1093/geront/42.1.92

Ratto EG, Videla F, Reyna Almandos JG, Maronna R (2018) Air quality at La Plata conglomerate. Review and prospective study to improve the present situation, Argentina

Reali D, Di Marino F, Bahramandpour S et al (1987) Micronuclei in exfoliated urothelial cells and urine mutagenicity in smokers. Mutat Res Lett 192:145-149. https://doi.org/10.1016/01657992(87)90112-6

Rosin MP (1992) The use of the micronucleus test on exfoliated cells to identify anti-clastogenic action in humans: a biological marker for the efficacy of chemopreventive agents. Mutation Res/Fundament Molec Mech Mutagen 267:265-276. https://doi.org/10.1016/00275107(92)90071-9

Roubicek DA, Gutiérrez-Castillo ME, Sordo M, Cebrián-García ME, Ostrosky-Wegman P (2007) Micronuclei induced by airborne particulate matter from Mexico City. Mutat Res 631(1):9-15

Sellappa S, Sadhanandhan B, Francis A, Vasudevan SG (2010) Evaluation of genotoxicity in petrol station workers in South India using micronucleus assay. Ind Health 48(6):852-856. https://doi. org/10.2486/indhealth.ms 1055

Silverman DT, Hartge P, Morrison AS, Devesa SS (1992) Epidemiology of bladder cancer. Hematology/oncology clinics of North America 6(1): $1-30$

Sosa BS, Banda Noriega R, Massolo L et al (2017) Human health risk due to variations in PM 10 -PM 2.5 and associated PAHs levels. Atmos Environ 160:27-35. https://doi.org/10.1016/j.atmosenv.2017.04. 004

Spivack SD, Hurteau GJ, Jain R, Kumar SV, Aldous KM, Gierthy JF, Kaminsky LS (2004) Gene-environment interaction signatures by quantitative mRNA profiling in exfoliated buccal mucosal cells. Cancer research 64(18):6805-6813.

Tolbert PE, Shy CM, Allen JW (1992) Micronuclei and other nuclear anomalies in buccal smears: methods development. Mutation Res/ Environ Mutagenesis Related Subjects 271:69-77. https://doi.org/ 10.1016/0165-1161(92)90033-I

Vidal ME (2018) Decreto N¹074-GPBA-18

Villarini M, Levorato S, Salvatori T, Ceretti E, Bonetta S, Carducci A, Grassi T, Vannini S, Donato F, Bonetta S, Verani M, De Donno A, Bonizzoni S, Bonetti A, Moretti M, Gelatti U, MAPEC LIFE Study Group (2018) Buccal micronucleus cytome assay in primary school children: a descriptive analysis of the MAPEC LIFE multicenter cohort study. Int J Hyg Environ Health 221(6):883-892

Vondracek M, Xi Z, Larsson P, Baker V, Mace K, Pfeifer A, Tjälve H, Donato MT, Gomez-Lechon MJ, Grafström RC (2001) Cytochrome P450 expression and related metabolism in human buccal mucosa. Carcinogenesis 22:481-488. https://doi.org/10.1093/carcin/22.3. 481

WHO (2006) Environmental Health Criteria 237. Principles for evaluating hsealth risks in children associated with exposure to chemicals 157237:351. https://www.inchem.org/documents/ehc/ehc/ehc237. pdf

WHO (2018) WHO global urban ambient air pollution database (update 2018). In: WHO. https://www.who.int/phe/health topics/ outdoorair/databases/cities/en/. Accessed 23 Apr 2019 
Wichmann FA, Müller A, Busi LE, Cianni N, Massolo L, Schlink U, Porta A, Sly PD (2009) Increased asthma and respiratory symptoms in children exposed to petrochemical pollution. J Allergy Clin Immunol 123:632-638. https://doi.org/10.1016/j.jaci.2008.09.052

World Medical Association (2001) World Medical Association Declaration of Helsinki. Ethical principles for medical research involving human subjects. Bull World Health Organ 79:373-374

Wultsch G, Nersesyan A, Kundi M, Jakse R, Beham A, Wagner KH, Knasmueller S (2014) The sensitivity of biomarkers for genotoxicity and acute cytotoxicity in nasal and buccal cells of welders. Int J Hyg Environ Health 217:492-498. https://doi.org/10.1016/J.IJHEH. 2013.09.005

Publisher's note Springer Nature remains neutral with regard to jurisdictional claims in published maps and institutional affiliations. 